УДК 336.74

\title{
СВІТОВИЙ ДОСВІД РОЗВИТКУ ЦИФРОВИХ ВАЛЮТ ЦЕНТРАЛЬНИХ БАНКІВ І ЙОГО ВПРОВАДЖЕННЯ В УКРAїHI
}

\author{
WORLD EXPERIENCE OF DEVELOPMENT \\ OF DIGITAL CURRENCIES OF CENTRAL BANKS \\ AND ITS IMPLEMENTATION IN UKRAINE
}

\author{
Чернишова Ольга Борисівна \\ кандидат економічних наук, доцент, \\ Одеський торговельно-економічний фаховий коледж \\ Київського національного торговельно-економічного університету \\ ORCID: https://orcid.org/0000-0002-5781-8044 \\ Возняковська Крістіна Анатоліївна \\ доктор юридичних наук, профресор, доцент, \\ Національний університет «Одеська юридична академія» \\ ORCID: https://orcid.org/0000-0002-0351-7107
}

\section{Башлай Сергій Вікторович}

кандидат економічних наук, доцент,

Сумський національний аграрний університет

ORCID: https://orcid.org/0000-0002-2247-5440

\section{Chernyshova Olga}

Odessa Trade and Economic Vocational College

of Kyiv National University of Trade and Economics

\author{
Vozniakovska Kristina \\ National University Odesa Law Academy \\ Bashlai Serhii \\ Sumy National Agrarian University
}

\begin{abstract}
У науковій статті визначено сутність та роль запровадження СBDC для економіки країни, описано її переваги для використання учасниками ринку. Досліджено країни, де проєкти CBDC запроваджені, пілотуються або досліджуються. Розкрито особливості форматів дизайну СВDC та відображено відмінні риси роздрібної та оптової (міжбанківської) версій CBDC. Визначено, що Україна входить у топ-10 роздрібних CBDC за Глобальним індексом, що враховує прогрес центральних банків, позицію щодо розвитку CBDC та суспільний інтерес при використанні у порівнянні з іншими країнами. На основі узагальнення та аналізу праць встановлено драйвери «E-hryvnia» в Україні. Встановлено, що запровадження CBDC на території України буде каталізатором есрективності платежів і представлятиме додаткову альтернативу поточній моделі грошей з операційної та технологічної точок зору. Враховуючи світовий досвід, наведено головні ризики запровадження в Україні CBDC та інтерпретовано релевантні заходи з їх нівелювання.
\end{abstract}

Ключові слова: CBDC, драйвери «E-hryvnia», версія CBDC, фрормат дизайну CBDC, ризики запровадження СBDC.

В научной статье определены сущность и роль внедрения CBDC для экономики страны, описаны ее преимущества для использования участниками рынка. Исследованы страны, где CBDC введены, пилотируются или исследуются. Раскрыты особенности форматов дизайна СBDC и отражены отличительные черты розничной и оптовой (межбанковской) версий CBDC. Определено, что Украина входит в топ-10 розничных CBDC по Глобальному индексу, учитывающему прогресс центральных банков, позицию развития CBDC и общественный интерес при использовании по сравнению с другими странами. На основе обобщения и анализа 
работ установлены драйверы E-hryvnia в Украине. Установлено, что внедрение CBDC на территории Украины будет катализатором эфффективности платежей и будет представлять дополнительную альтернативу текущей модели денег с операционной и технологической точки зрения. Учитывая мировой опыт, приведены главные риски внедрения в Украине CBDC и интерпретированы релевантные меры по их нивелированию.

Ключевые слова: CBDC, драйверы E-hryvnia, версия CBDC, фрормат дизайна CBDC, риски внедрения CBDC.

Based on the results of research, the essence and role of the introduction of CBDC for the country's economy are determined, its advantages for use by market participants are described. The countries where CBDC projects are implemented, piloted or researched are studied. A retrospective analysis of the implementation of CBDC by central banks was conducted and it was substantiated that CBDC has the potential for synergy with private payment decisions and creating a positive contribution to the formation of innovative, competitive and sustainable payment system in different regions. The peculiarities of CBDC design formats are revealed and the distinctive features of retail and wholesale (interbank) versions of CBDC are reflected, the reasons for their issue and use are reflected. The specifics of direct, hybrid and indirect retail CBDC are interpreted. It is determined that Ukraine is in the top 10 retail CBDCs according to the Global Index, which takes into account the progress of central banks, the position on the development of CBDC and public interest in use, compared to other countries. Based on the generalization and analysis of works, E-hryvnia drivers have been installed in Ukraine. It was identified that the introduction of CBDC in Ukraine will significantly complicate the work of commercial banks and will require radical changes in the implementation of innovative compatible products. Based on the results of the study of successful global experience of CBDC implementation by central banks, key focuses are proposed and a description of changes in the introduction of "E-hryvnia" in Ukraine. It is established that the introduction of CBDC in Ukraine will be a catalyst for payment efficiency and will be an additional alternative to the current money model from an operational and technological point of view. Taking into account the world experience, the main risks of CBDC introduction in Ukraine are given and relevant measures for their leveling are interpreted.

Keywords: CBDC, E-hryvnia drivers, CBDC version, CBDC design format, risks of CBDC implementation.

Постановка проблеми. Цифрова трансорормація економіки та швидкі темпи запровадження, пілотування і дослідження циорових валют є каталізаторами розвитку економіки в умовах глобалізації та інтернаціоналізації. Такі тенденції змінюють міжнародний валютний ландшафт та потребують нових підходів і своєчасних змін платіжної інфрраструктури. У цьому контексті суттєвого значення має врахування особливостей, механізму, потенційного ефекту і можливих наслідків від впровадження цифрової валюти центрального банку («Central bank digital currencies», далі-CBDC).

Аналіз останніх досліджень і публікацій. Теоретичні засади CBDC та підходи до їі класифрікації наведено у працях вітчизняних та зарубіжних вчених, серед яких: Ейдан Д. [1], Запорожець С. [12], Калле Дж. [1], Наторіна А. [8-9], ХуторнаМ. [12]. Практичні аспекти впровадження CBDC у різних країнах відображено, зокрема, у наукових працях Калле Дж. [1], Ніпелта Д. [5], Шаповал Ю. [13], Шкляр А. [7], а також у звітах міжнародних інституцій та компаній - Міжнародний валютний фронд [4], «Deloitte» [3], «РwC» [6]. Доцільність, покрокова стратегія, перспективи та впровадження CBDC окреслено Національним банком України [10-11]. Науковці Сантяго Ф., Метіль А., Подцерковний О., Возняковська К., Олюха В [14] досліджують правові аспекти використання технології блокчейн. Активна цифрова трансорормація економіки України та постійні зміни зовнішнього середовища підкреслюють важливість та актуальність проведення подальших досліджень за цією тематикою.

Мета дослідження полягає у визначенні драйверів «E-hryvnia» в Україні, розробці пропозицій щодо ключових фокусів запровадження «E-hryvnia», а також ідентифікації головних ризиків CBDC на території України й інтерпретації релевантних заходів з їх нівелювання.

Виклад основного матеріалу дослідження. Відповідно до [1; 3; 7; 9] CBDC - це цифрова фрорма грошей центрального банку, яка може широко використовуватися домогосподарствами та підприємствами для здійснення платежів, тобто це традиційні гроші в цифровій формі, що випускаються центральним банком країни та засновані на цисрровому обліковому записі. CBDC є законним платіжним засобом із зобов'язаннями центрального банку, подібно до фрізичної валюти в обігу. Це робить CBDC більш безпечною і менш нестабільною, ніж інші цифрові валюти. СBDC швидко розвивається, а різні центральні банки використовують дисреренційовані підходи до її впровадження. Така валюта $€$ новою фрормою грошей центрального банку та утворює зміну парадигм в платіжній інорраструктурі.

Потреба у CBDC зумовлена швидкою цифрровізацією економіки, стимулом до платежів і розрахунків у режимі реального часу, а також потребою в більш ефрективній внутріш- 
ній та транскордонній валютній взаємодії. За даними Міжнародного валютного фонду [4], CBDC здатна зменшити витрати, полегшити безперебійний обіг грошей, покращити фрінансову доступність і забезпечити безпечний доступ до грошей через цифрові канали. 3 іншого боку, багато центральних банків також усвідомлюють зростаючий вплив CBDC і стурбовані потенційним впливом на фрінансову систему [12]. Результати опрацювання наукових робіт $[1 ; 5 ; 7 ; 12-13]$ дозволяють зробити висновок про те, що СВDС може бути універсальним інструментом, який покращує грошово-кредитну політику.

Вбачаючи великі можливості для покращення монетарної та фріскальної політики, центральні банки приділяють значну увагу CBDC. На рис. 1 відображено країни, в яких проєкти CBDC запроваджені, пілотуються або досліджуються (рис. 1).

3гідно рис. 1, запровадили CBDC: Багамські острови, Камбоджа, Східні Кариби (до складу яких входять Сент-Кітс і Невіс, Сент-Вінсент і Гренадіни, Сент-Люсія, Гренада, Домініка, Кариби, Антигуа і Барбуда).
Пілотування CBDC здійснюють: Еквадор, Китай, Республіка Корея, Сінгапур, Туреччина, Україна, Уругвай, Швеція, Ямайка, Японія. Досліджують СBDC: Австралія, Бахрейн, Бразилія, Бруней, Велика Британія, Гана, Ісландія, Індія, Індонезія, Канада, Кенія, Мадагаскар, Маврикій, Марокко, Нова Зеландія, Норвегія, Південна Африка, Суринам, Таїланд, Туніс, США, Фінляндія, Чехія.

Хоча такі країни, як Китай, Швеція, Канада та Велика Британія, протягом останніх кількох років керували дослідницькими та пілотними проєктами, фрактичне виконання пілотних CBDC здійснюють менші країни. Так, Багамські острови вже запустили «Sand Dollar» у 2020 р. Це цифрова версія Багамського долара, що випускається Центральним банком Багамських островів через уповноважені фрінансові установи. Жителі можуть використовувати цифррову валюту через додатки для мобільних телефонів або за допомогою фрізичної платіжної картки для доступу до цифрового гаманця. «Sand Dollar» забезпечений валютними резервами Центрального банку та обмежений для внутрішнього використання [3].

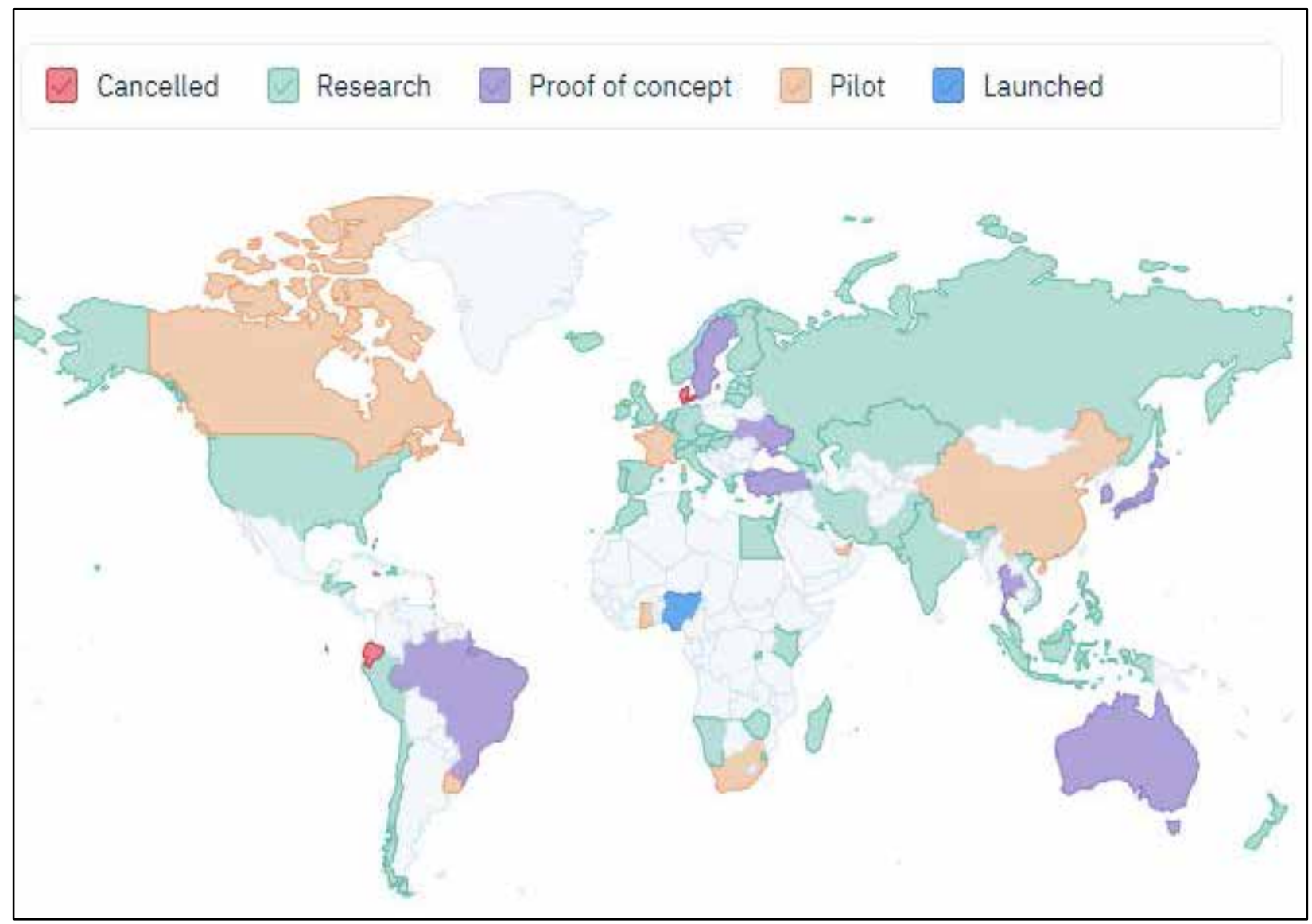

Рис. 1. Країни, в яких проєкти СВDС запроваджені, пілотуються або досліджуються станом на грудень 2021 року

Джерело: побудовано за даними [2] 
Центральний банк Східного Карибського басейну (ЕССВ) пілотує свою цифрову валюту «DCash»учотирьох країнахстаном наберезень 2021 року. Споживачі та підприємства можуть використовувати смарт-додатки для здійснення фрінансових операцій, проте «DCash» не можна використовувати для транзакцій за межами Східно-Карибського валютного союзу [1; 13]. Новий уряд на Маршаллових островах відмовляється від зусиль попереднього уряду запустити «SOV». У 2020 році Центральний банк Бразилії оголосив про плани запуску цифррової валюти до 2022 року. У 2021 році Центральний банк оголосив про відтермінування запуску на два-три роки. Проєкт цифрової валюти Китаю зосереджений на внутрішньому ринку, але Центральний банк тестує транскордонні транзакції з Гонконгом. Китай також працює над розширенням транскордонних випробувань 3 центральними банками Таїланду та OAE $[1 ; 5 ; 12]$.

Центральні банки також мають різні часові рамки для тестування, розробки та запуску, і ці терміни часто змінюються. Наприклад, у березні 2021 року Європейський центральний банк (ЄЦБ) оголосив чотирирічний термін для створення цифрового євро. Центральний банк Туреччини вперше оголосив про свою зацікавленість у цифровій валюті в січні 2021 року і має намір запустити пілотну програму через шість місяців. Швеція, навпаки, досліджувала циоррові валюти протягом трьох років, перш ніж перейти до тестування. Існує багато припущень про те, коли Китай офріційно запустить свою цифрову валюту.

Крім того, згідно [11] центральні банки розглядають різні варіанти дизайну своїх цифрових валют. Зокрема, «Sand Dollar» $\mathrm{i}$ «DCash» призначені лише для внутрішнього використання, тоді як Китай прагне розширити своє тестування транскордонних операцій з організаціями в Гонконзі, включивши в нього Таїланд та Об'єднані Арабські Емірати (ОАЕ). Центральні банки Франції та Швейцарії також тестують транскордонні трансакції CBDC. Хоча більшість циоррових валют, які розглядаються, будуть або є безпосередньо доступними для споживачів, Саудівська Аравія та ОАЕ вивчають цифрову валюту спеціально для міжбанківських транзакцій (оптове використання). Центральні банки Саудівської Аравії та OAE співпрацюють над створенням спільної цифррової валюти «Aber» для міжбанківських грошових переказів, продовжують дослідження та уточнення валюти, завершивши пілотний етап наприкінці 2020 року. Венесуела запус- тила цифрову валюту «Petro» у 2018 році, яка нібито забезпечена запасами нафти, природного газу та корисних копалин і керується за допомогою технології блокчейн. «Petro» не була прийнята для загального використання, і мало доказів того, що це фрункціональна або оперативна цифрова валюта.

У грудні 2018 року Національний банк України запровадив цифррову валюту «E-hryvnia» [10-11]. Проєкт включав тестування розподілених бухгалтерських книг, фрормулювання попередньої основи та положень, встановлення тимчасової моделі обліку та дослідження різного впливу.

Сучасні міжнародні зусилля щодо проєктів CBDC зосереджені на дизайні, базових технологіях та перевагах CBDC. Встановлено, що CBDC має потенціал для синергії 3 приватними платіжними рішеннями та створення позитивного внеску в фрормування інноваційної, конкурентоспроможної та стійкої платіжної системи в різних регіонах. Це дозволить цифровізувати економіку та досягти інновацій у всіх платіжних і грошово-кредитних системах. Завдяки CBDC можна здійснювати ефективніші, швидші та безпечні транскордонні платежі, забезпечуючи плавний міжнародний потік капіталу. Однак успіх CBDC значною мірою залежить від ефективності як справжньої альтернативи готівці серед користувачів, включаючи приватних споживачів, фрінансових посередників та центральні банки. Тобто успіх CBDC залежить від її фрункціональності як кращого та стабільнішого засобу обміну.

Центральні банки вивчають варіанти дизайну CBDC, зважаючи на такі фрактори, як доступ, коноріденційність і метод поширення. Існує два поширені фрормати дизайну CBDC [1; $3 ; 5 ; 11]$ : на основі токенів і на основі облікового запису. На базі вивчення та аналізу [1; 3; 5] визначено, що кожен фрормат має різну технічну інфрраструктуру, а також різні рівні доступу та коноріденційності:

1. СBDC на основі токенів використовують цифрровий токен, а доступ і претензії вимагають від користувачів знання токена (пара публічно-приватних ключів). Цей підхід забезпечує високий ступінь анонімності; однак центральні банки можуть запровадити вимоги до ідентисрікації для використання мережі. Перекази токенів залежать від здатності відправника перевірити дійсність об'єкта платежу і, отже, вимагають фрорми технології розподіленої книги для перевірки ланцюга власності в кожному токені та перевірки платіжних транзакцій. Це також означає більший ризик кінце- 
вого користувача втратити ключ або токен, які зберігаються в гаманці, який не зберігається. У підході, заснованому на токенах, для переказу коштів банки обробляють кожен платіж, дебетуючи рахунок CBDC відправника та кредитуючи рахунок CBDC одержувача. Транзакції перевіряються за допомогою ідентисрікаційних даних користувачів, тому для підтримки унікального ідентисрікатора кожної особи в усіх платіжних системах необхідні надійні системи керування ідентиорікацією.

2. У підході, що ґрунтується на обліковому записі, перевірка переказів у системі на основі облікових записів залежить від встановлення відповідних засобів захисту від крадіжки особистих даних, шахрайства та несанкціонованих переказів із дійсних облікових записів. Вибір фрормату дизайну залежить від політичної цілі центрального банку. Національна CBDC може бути новим інструментом монетарної політики центрального банку i, таким чином, впливати на цілі його політики. Різні фрормати СBDC мають різний вплив на платіжні системи, грошово-кредитну політику, а також на структуру та стабільність фрінансової системи. CBDC провокує макроекономічні зміни за рахунок прямого впливу на вибір порторелю домогосподарств.

Іншим важливим аспектом CBDC є єії версії $[3 ; 6]:$

1) роздрібна - для здійснення роздрібних платежів населенням;

2) оптова (міжбанківська) - для проведення міжбанківських розрахунків фрінансових установ.

У роздрібних та оптових версіях CBDC існує декілька видів.

Оптова CBDC - це останній крок на 50-річному шляху центральних банків до використання нових технологій для підвищення ефрективності та стійкості системи оптових платежів у певній валютній зоні. Це зробило оптову СВDC ідеальним раннім проєктом блокчейн, оскільки мережа користувачів i учасників вже була фріксована, а центральні банки оновлюють або вивчають технічні вдо- сконалення своїх систем RTGS (валових розрахунків у реальному часі) кожні 5-7 років. Тим часом, інтерес до ефективності роздрібної CBDC зріс, і центральні банки по всьому світу проводять дослідження та приступають до підтвердження концепції.

Роздрібна CBDC може безпосередньо зберігатися громадянами та юридичними особами як цифррова фрорма готівки та доповнення до паперових грошей і як цифровий еквівалент банкнот і монет, центральні банки пропонують нові платформи для зберігання CBDC.

3 точки зору доступу та правового позову, роздрібна CBDC може бути прямою, непрямою або гібридною (табл. 1).

Причини випуску та використання CBDC суттєво відрізняються залежно від конкретного центрального банку та існуючих платіжних систем. Зокрема, для запровадження роздрібної CBDC мотивація центральних банків включає сприяння фрінансовому залученню, збільшення доходу від сеньйораж, сприяння грошово-кредитній політиці, пов'язування платежів з ідентичністю, надання можливості участі в токенізованій фрінансовій екосистемі, стимулювання конкуренції в приватному секторі, надання альтернативи готівкою або іншим чином.

Розрив між інноваціями центрального банку на оптовому рівні та інноваціями «FinTech» на рівні роздрібної торгівлі незабаром може зменшитися. Центральні банки, які планують випускати роздрібну CBDC, мають проаналізувати досвід запровадження оптових проєктів CBDC та використати його, як підґрунтя для прийняття зважених рішень. У той же час нові моделі показують, що архітектура CBDC на основі токенів, що використовує блокчейн, може забезпечувати зв'язки між оптовими та роздрібними учасниками, які раніше не існували.

У 2021 році для вимірювання рівня зрілості центрального банку у запровадженні власної CBDC компанією «PwC» [6] було визначено Глобальний індекс CBDC, що враховує прогрес центральних банків, позицію щодо розвитку CBDC та суспільний інтерес при викорис-

Види роздрібної CBDC

Таблиця 1

\begin{tabular}{|l|l|l|}
\hline \multicolumn{1}{|c|}{ Пряма CBDC } & \multicolumn{1}{c|}{ Гібридна СBDC } & \multicolumn{1}{c|}{ Непряма СВDC } \\
\hline - СВDC - це пряма вимога & - СВDC - це пряма вимога & - позов СВDC належить \\
до центральних банків; & до центральних банків; & посереднику; \\
- центральні банки & - центральні банки & - роздрібними платежами \\
обробляють платежі & періодично обробляють & займаються посередники, a \\
безпосередньо & роздрібні залишки & оптовими - центральні банки \\
\hline
\end{tabular}

Джерело: побудовано за даними [3; 6] 
Таблиця 2

Топ-10 роздрібних CBDC станом на квітень 2021 року

\begin{tabular}{|c|c|c|c|c|}
\hline Назва СBDC & Країна & Регіон & $\begin{array}{c}\text { Глобальний } \\
\text { рейтинг }\end{array}$ & $\begin{array}{c}\text { Значення індексу } \\
\text { роздрібної СвDC }\end{array}$ \\
\hline Sand Dollar & Багамські острови & Америка & 1 & 92 \\
\hline Bakong & Камбоджа & Азія & 2 & 83 \\
\hline DC/EP & Материковий Китай & Азія & 3 & 75 \\
\hline E-hryvnia & Україна & Європа & 4 & 71 \\
\hline E-peso & Уругвай & Америка & 4 & 71 \\
\hline Dinero electronico & Еквадор & Америка & 4 & 71 \\
\hline DXCD & Східні Кариби & Америка & 7 & 61 \\
\hline E-krona & Швеція & Європа & 8 & 58 \\
\hline E-won & Корея & Азія & 9 & 51 \\
\hline Digital Lira & Туреччина & Азія & 10 & 42 \\
\hline
\end{tabular}

Джерело: побудовано за даними [6]

танні роздрібної та оптової (міжбанківської) CBDC. У табл. 2 наведено 10 найбільших роздрібних СВDС станом на квітень 2021 року.

Як видно 3 табл. 2, ініціативи роздрібної CBDC особливо сильні в країнах, що розвиваються, де фрінансове залучення, цифровізація та цифррова трансорормація є ключовими рушійними фракторами. Україна 3 «E-hryvnia» у глобальному рейтингу посіла 4 місце, адже значення індексу роздрібної CBDC становить 71, що свідчить про результативні дії країни у пілотуванні проєкту та реалізації відповідних заходів.

За результатами узагальнення та аналізу праць [5; 9; 10-11], встановлено драйвери «E-hryvnia» в Україні сприятимуть:

1) підтримці та впорядковуванню фрункцій Національного Банку України щодо надання законного платіжного засобу та забезпечення постійного доступу в цифровій економіці;

2) забезпеченні доступу до цифррових платежів $з$ мінімальною або нульовою ціною через новий універсальний електронний платіжний засіб;

3) зменшенню операційних витрат і ризиків, пов'язаних з управлінням фрізичною валютою;

4) зменшенню бар'єрів для входу шляхом створення відкритої інфрраструктури для стимулювання інновацій та участі приватних гравців;

5) підвищенню ефрективності платіжних систем у точках продажу й у Р2P;

6) покращенню міжбанківських платежів за рахунок прискорення розрахунків та відкритого чи подовженого часу проведення розрахунків;

7) покращенню грошово-кредитної політики, спрощенню розподілу державних пільг фрізичним особам та покращенню контролю за операціями для податкового контролю;
8) підвищенню фрінансової стабільності, скороченню ліквідності;

9) забезпеченню цілісності макроекономічних даних;

10) підвищення конкурентоспроможності місцевої валюти як засобу платежу.

Загалом, запровадження CBDC в Україні сприятиме формуванню стійкого ландшафрту платежів, підтримуючи конкуренцію, ефективність, контроль та інновації. Вона дозволить зменшити обсяги використання готівки, а також підвищить зручність використання.

Запровадження CBDC в Україні здійснить значний вплив на модернізацію міжнародного валютного ландшафту. Це створить численні можливості для подальшої цифрової трансфрормації підприємств та фрінансових установ, у тому числі, у частині їх інтеграції в платіжну та фрінансову інфрраструктуру. Однак, використання зазначених можливостей вимагає від України оновлення операційного, правового та регуляторного процесів, а також потребує узгодження заходів бухгалтерського обліку та внутрішнього контролю.

Впровадження в Україні CBDC значно ускладнить роботу комерційних банків і потребуватиме кардинальних змін, щоб не відставати від необхідності впроваджувати інноваційні сумісні продукти. Тому комерційні банки, які зосереджені на операціях із клієнтами, безпечних транзакціях та нормативній звітності, мають виступити важливими партнерами в успішному впровадженні СBDC. Ґрунтуючись на результатах вивчення успішного світового досвіду впровадження центральними банками CBDC [1; 3; 5-13], запропоновано ключові фрокуси та надано характеристику змін при запровадженні «E-hryvnia» в Україні (табл. 3). 
Таблиця 3

Ключові фокуси та характеристика змін при запровадженні «Е-hryvnia» в Україні

\begin{tabular}{|c|c|}
\hline Ключовий фокус & Характеристика змін \\
\hline Бізнес-модель & $\begin{array}{l}\text { - впровадження інноваційних продуктів та послуг з метою } \\
\text { ефективного використання та адаптації згідно з можливостями } \\
\text { СВDС (наприклад, розробка автономної платіжної } \\
\text { інфраструктури або електронного сховища для зберігання } \\
\text { СВDС певних установ); } \\
\text { - наявність великих обсягів даних про транзакції у реальному часі; } \\
\text { - припинення кореспондентських банківських мереж }\end{array}$ \\
\hline Регулювання & $\begin{array}{l}\text { - редормування законодавчої бази на основі дизайну CBDC; } \\
\text { - боротьба з шахрайством }\end{array}$ \\
\hline Технологія & $\begin{array}{l}\text { - адаптування інфраструктури для обробки транзакцій СBDC; } \\
\text { - покращення цифрової програми для впровадження фрункціональних } \\
\text { можливостей СВDС, використовуючи поточні процеси; } \\
\text { - розвиток інтерфейсів клієнтів }\end{array}$ \\
\hline $\begin{array}{l}\text { Управління ідентифрікацією } \\
\text { та верифрікацією }\end{array}$ & $\begin{array}{l}\text { - удосконалення інфрраструктури для управління ідентифрікацією } \\
\text { та верифікацією }\end{array}$ \\
\hline Кібербезпека & - проактивне забезпечення конфіденційності і безпеки даних \\
\hline
\end{tabular}

Запровадження CBDC «E-hryvnia» в Україні буде каталізатором ефективності платежів і представлятиме додаткову альтернативу поточній моделі грошей з операційної та технологічної точок зору. Враховуючи світовий досвід [5-8; 12-13] та прогнози [3-4; 10-11], хоча CBDC принесе переваги для економіки, її запровадження в Україні потребує нівелювання ризиків. Нижче наведено головні ризики запровадження в Україні CBDC $з$ релевантними заходами щодо їх нівелювання.

1. Конфріденційність даних. Особи, які володіють CBDC, потенційно можуть отримати доступ до особистих даних, особливо у випадку роздрібних токенів. Таким чином, зберігання великої кількості даних у централізованій системі завжди потребує забезпечення конфріденційності на високому рівні.

2. Високонадійність та постійна доступність. Адаптація існуючих платіжних систем або створення нової системи 3 нуля суттєво вплине на поточну операційну модель. Навіть незначні зміни того, що лежить в основі повсякденної економічної діяльності банків і громадян, можуть мати серйозний вплив на надійність і доступність платіжних систем. Слід правильно оцінювати технологічні та операційні проблеми запровадження CBDC, оскільки метою в кінцевому підсумку має бути забезпечення в режимі реального часу, високонадійної та постійно доступної платіжної системи із залученням зацікавлених сторін у різних країнах.

3. Кібербезпека. Враховуючи зростання поширеності кібератак за останні кілька років [1; 2-8; 12-13], безпека має бути основним ком- понентом системи CBDC. Хоча кіберзагрози вже $є$ частиною поточних ризиків платіжної, клірингової та розрахункової системи, впровадження роздрібної CBDC потребує вирішення проблеми стійкості до кіберзагроз, тому що вона відкрита для великої кількості учасників. Це робить систему більш вразливою.

4. Фінансові ризики, нівелювання яких потребує внесення необхідних поправок щодо санкцій або процедур належної обачності. Також слід ретельно оцінити вплив транскордонних платежів CBDC на вимоги щодо боротьби з фрінансуванням тероризму.

5. Правове регулювання. Випуск роздрібної CBDC може створити певні правові складнощі, що випливають із можливого припинення банківського посередництва, адже емісія CBDC буде неважливою технологічною модернізацією. Нівелювання цього ризику потребує реалізацію комплексу заходів, що спрямовані на своєчасне фрормування та оновлення нормативно-правової бази.

Висновки 3 проведеного дослідження. За результатами опрацювання наукових праць визначено сутність та роль запровадження CBDC для економіки країни, описано iї переваги для використання учасниками ринку. Здійснено ретроспективний аналіз впровадження CBDC центральними банками та розкрито особливості срорматів дизайну, версій і видів CBDC, відображено причини їх випуску та використання. Визначено, що Україна входить у топ-10 роздрібних CBDC за Глобальним індексом, що враховує прогрес центральних банків, позицію щодо роз- 
витку CBDC та суспільний інтерес при використанні, у порівнянні з іншими країнами. На основі узагальнення та аналізу праць, встановлено драйвери «E-hryvnia» в Україні. Ґрунтуючись на результатах вивчення успішного світового досвіду впровадження централь- ними банками CBDC, запропоновано ключові фрокуси і надано характеристику змін при запровадженні «Е-hryvnia». Враховуючи світовий досвід, наведено головні ризики запровадження в Україні CBDC та інтерпретовано релевантні заходи з їх нівелювання.

\section{СПИСОК ВИКОРИСТАНИХ ДЖЕРЕЛ:}

1. Calle G., Eidan D. Central Bank Digital Currency: an innovation in payments. 2020. R3, White Paper, 24 p.

2. Central Bank Digital Currency Tracker. 2021. URL: https://cbdctracker.org/

3. Deloitte. Are Central Bank Digital Currencies (CBDCs) the money of tomorrow? 2021. URL: https://www2.deloitte. $\mathrm{com} /$ content/dam/Deloitte/lu/Documents/financial-services/Banking/lu-are-central-bank-digital-currencies.pdf

4. International Monetary Fund. 2021. URL: https://www.imf.org/en/Home

5. Niepelt D. Central Bank Digital Currency: Considerations, Projects, Outlook. Centre for economic policy research. 2021. 162 p.

6. PwC Global CBDC Index 2021. URL: https://www.pwc.com/gx/en/industries/financial-services/assets/pwccbdc-global-index-1st-edition-april-2021.pdf

7. Shkliar A. I. The phenomenon of central banks' digital currencies (CBDC): key attributes and implementation perspectives. Ukrainian Society. 2020. Vol. 1(72). P. 123-137. DOI: https://doi.org/10.15407/socium2020.01.123

8. Наторіна А. О. Синкретичність менеджменту цифрових ризиків та інформаційної безпеки. Вісник Житомирського державного технологічного університету. Серія : економіка, управління та адміністрування. 2019. Вип. 3(89). С. 30-34. DOI: https://doi.org/10.26642/ema-2019-3(89)-30-34

9. Наторіна А. О. Цифрові тренди: глобальний та національний аспекти. Економічний простір : Збірник наукових праць. 2018. № 130. С. 14-22. URL: http://www.prostir.pdaba.dp.ua/index.php/journal/ article/view/183

10. Національний банк України. Аналітична записка за результатами пілотного проєкту «Е-гривня». 2019. URL: https://bank.gov.ua/admin_uploads/article/Analitichna_zapiska_E-grivnya.pdf?v=4

11. Національний банк України. Стратегія розвитку фінансового сектору України до 2025 року (оновлена у березні 2021 року). 2021. URL: https://bank.gov.ua/admin_uploads/article/Strategy_FS_2025.pdf?v=4

12. Хуторна М. Е., Запорожець С. В., Ткаченко Ю. П. Цифрові валюти центральних банків: світові тренди та перспективи в Україні. Соціальна економіка. 2021. Вип. 61. С. 123-134. DOI: https://doi.org/10.26565/25242547-2021-61-12

13. Шаповал Ю. Цифрові валюти центральних банків: досвід пілотних проєктів та висновки для НБУ. Економіка і прогнозування. 2020. № 4. С. 103-122.

14. Santiago F., Metil A., Podtserkovnyi O., Vozniakovska K., Oliukha V. Legal Aspects of Blockchain Technology Use. Journal of Legal, Ethical and Regulatory. 2019. Vol. 22. Issues 6. P. 1-6.

\section{REFERENCES:}

1. Calle G., Eidan D. (2020) Central Bank Digital Currency: an innovation in payments. R3, White Paper, 24 p.

2. Central Bank Digital Currency Tracker (2021). Retrieved from: https://cbdctracker.org/

3. Deloitte. Are Central Bank Digital Currencies (CBDCs) the money of tomorrow? (2021). Retrieved from: https://www2.deloitte.com/content/dam/Deloitte/lu/Documents/financial-services/Banking/lu-are-central-bank-digital-currencies.pdf

4. International Monetary Fund (2021). Retrieved from: https://www.imf.org/en/Home

5. Niepelt D. (2021) Central Bank Digital Currency: Considerations, Projects, Outlook. Centre for economic policy research, $162 \mathrm{p}$.

6. PwC Global CBDC Index 2021. Retrieved from: https://www.pwc.com/gx/en/industries/financial-services/ assets/pwc-cbdc-global-index-1st-edition-april-2021.pdf

7. Shkliar, A. I. (2020) The phenomenon of central banks' digital currencies (CBDC): key attributes and implementation perspectives. Ukrainian Society, 1(72), 123-137. DOI: https://doi.org/10.15407/socium2020.01.123

8. Natorina, A. O. (2019) Synkretychnistj menedzhmentu cyfrovykh ryzykiv ta informacijnoji bezpeky [Digital trends: global and national aspects]. Visnyk Zhytomyrsjkogho derzhavnogho tekhnologhichnogho universytetu. Serija: ekonomika, upravlinnja ta administruvannja - Economic space: Collection of scientific works, 3(89), 30-34. DOI: https://doi.org/10.26642/ema-2019-3(89)-30-34 
9. Natorina, A. O. (2018) Cyfrovi trendy: ghlobaljnyj ta nacionaljnyj aspekty [Digital trends: global and national aspects]. Ekonomichnyj prostir: Zbirnyk naukovykh pracj - Economic space: Collection of scientific works, 130 , 14-22. Retrieved from: http://www.prostir.pdaba.dp.ua/index.php/journal/article/view/183

10. Nacionaljnyj bank Ukrajiny. Analitychna zapyska za rezuljtatamy pilotnogho projektu «E-ghryvnja» (2019). Retrieved from: https://bank.gov.ua/admin_uploads/article/Analitichna_zapiska_E-grivnya.pdf?v=4

11. Nacionaljnyj bank Ukrajiny. Strateghija rozvytku finansovogho sektoru Ukrajiny do 2025 roku (onovlena u berezni 2021 roku) (2021). Retrieved from: https://bank.gov.ua/admin_uploads/article/Strategy_FS_2025.pdf?v=4

12. Khutorna, M. E., Zaporozhecj, S. V., Tkachenko, Ju. P. (2021) Cyfrovi valjuty centraljnykh bankiv: svitovi trendy ta perspektyvy $v$ Ukrajini [Digital currencies of central banks: global trends and prospects in Ukraine]. Socialjna ekonomika - Social economy, 61, 123-134. DOI: https://doi.org/10.26565/2524-2547-2021-61-12

13. Shapoval, Ju. (2020) Cyfrovi valjuty centraljnykh bankiv: dosvid pilotnykh projektiv ta vysnovky dlja NBU [Digital currencies of central banks: the experience of pilot projects and conclusions for the NBU]. Ekonomika $i$ proghnozuvannja - Economics and forecasting, 4, 103-122.

14. Santiago, F., Metil, A., Podtserkovnyi, O., Vozniakovska, K., Oliukha, V. (2019) Legal Aspects of Blockchain Technology Use. Journal of Legal, Ethical and Regulatory, vol. 22, iss. 6, pp. 1-6. 